\title{
What will get sick from the slick?
}

\section{Nature investigates five of the Gulf of Mexico's signature species.}

Far from the tar-coated beaches and clean-up crews seen on nightly news programmes, the Deepwater Horizon disaster is exacting an ongoing and largely unknown toll. In the open waters of the Gulf of Mexico, floating oil slicks and subsurface plumes threaten a highly diverse ecosystem. According to a 2009 inventory by the Harte Research Institute (HRI) for Gulf of Mexico Studies at Texas A\&M University in Corpus Christi, the area around the ill-fated rig hosts 1,728 species, among them whale sharks, tarpon, tuna, sea turtles and sperm whales. With no end in sight for the spill, researchers are now struggling to understand the scope and nature of the damage to deep-ocean ecosystems through some of the Gulf's largest residents.

"The greatest part of the Gulf ecosystem is out of sight beneath the surface," says Larry
McKinney, executive director of the HRI. This largely unmonitored region, he adds, is "incredibly sensitive to the toxic effects of oil and dispersant", as well as to the low oxygen levels associated with deep-water plumes.

Studies of the 1989 Exxon Valdez spill in Alaska show that oil ingested by marine life accumulates in tissues, lowers reproductive rates and increases disease and mortality rates (in Loughlin, T. R. (ed.) Marine Mammals and the Exxon Valdez; Academic, 1994). The blowout of the Ixtoc I offshore well in Mexico's Bay of Campeche, which spewed some 530 million litres of oil into the Gulf between June 1979 and March 1980, gave similar results. That spill hit a less environmentally sensitive shoreline than Deepwater Horizon, and the oil broke down faster than expected in warm waters and sunlight. Even so, it reduced or threatened populations of coral, sea turtles, shrimp and fish.

By comparison, the Deepwater Horizon rig was anchored in waters more than 30 times deeper than Ixtoc I, near the nutrient-laden outflow of the Mississippi where many species feed and reproduce. Yet these open-ocean dwellers have effectively been overlooked in the effort to assess and limit the spill's impact.

"If animals are dying and we don't know now, then we won't ever know," says Eric Hoffmayer, a researcher at the University of Southern Mississippi's Gulf Coast Research Laboratory in Ocean Springs. Here, Nature presents a snapshot of the known and unknown effects of the spill on five of the Gulf's signature species.

\section{Melissa Gaskill}

See www.nature.com/oilspill for more.

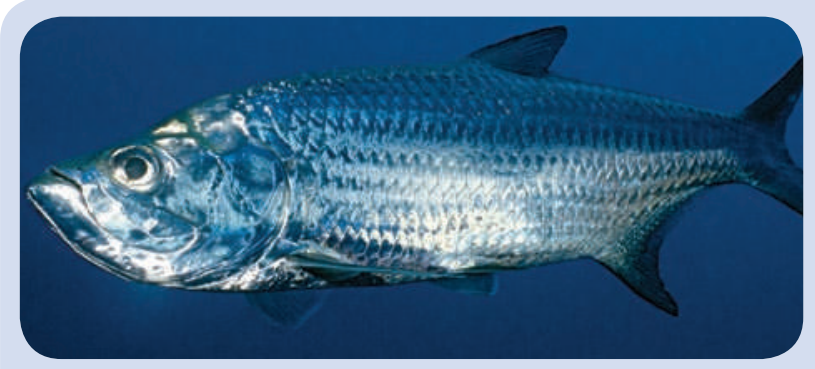

Species: Tarpon (Megalops atlanticus)

Risk: Ingestion of oiled prey diverts metabolic energy from the fish's other needs. Oil and dispersants can coat gills and primitive lungs (which are used to breathe at the surface).

Exposure: Unknown. Historical tag data confirm that adult tarpon feed in the spill area, and tarpon larvae are likely to have been exposed to oil.
With adults weighing 70-160 kilograms, the formidable tarpon is a popular game fish. The Gulf hosts two tarpon populations, says McKinney: one that spawns off Mexico's Yucatán peninsula and follows the Texas coast to northern waters, and another that spawns offshore near Florida. Spawning peaks between May and July, after which larvae move as plankton back to coastal and inshore waters. This life cycle gives plenty of opportunity to encounter contaminated water near the spill site, although data are scarce. "We don't have any tags on tarpon this year," McKinney says. "We need planes or ships to make visual observations." McKinney has scheduled a research cruise for August to look at oil plumes north and east of the spill site near deep-water coral communities, and to sample for tarpon, among other species, around the Flower Garden Banks National Marine Sanctuary, some 500 kilometres west of the well head.

"We need to know where the plumes are and what is in them how much methane, how much dispersant, the concentration of oil - and how they are affecting marine life," he adds. "There are more unknowns than knowns right now."

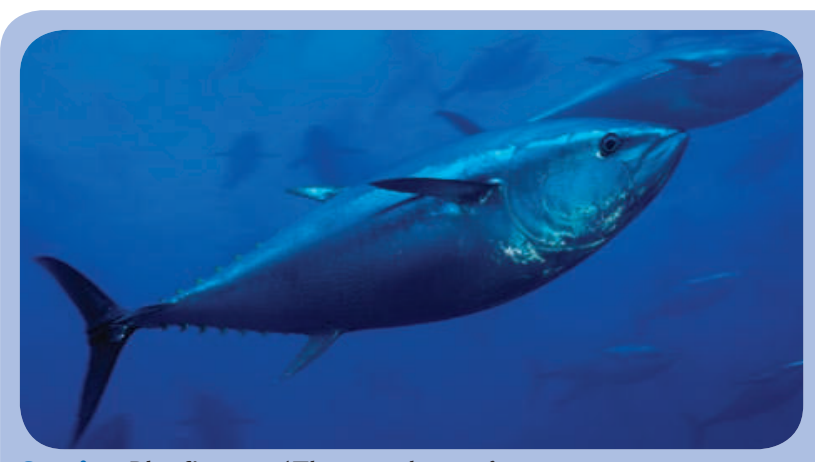

Species: Bluefin tuna (Thunnus thynnus)

Risk: Oil causes larvae deformation and death.

Exposure: Unknown, but larvae have probably already encountered oil. Tagged tuna are known to occupy the Loop Current, which circulates through the Gulf and into the Atlantic Ocean and is now drawing oil into its flow.
The northern Gulf of Mexico is a crucial breeding ground for the Atlantic bluefin tuna, one of the world's most important commercial fish. When the tuna spawned in April and May, they were south of the oil, but currents could carry larvae into the spill, says HRI conservation scientist Tom Shirley. Studies of the Ixtoc I spill revealed that fish are particularly vulnerable to oil early in their lives, says Joan Holt, associate director for mariculture at the University of Texas Marine Science Institute. When fish eggs were placed in sea water containing Ixtoc oil that had weathered for two months, the hatched larvae were deformed and all died within a few days (S. C. Rabalais et al. Tex. J. Sci. 33, 33-38; 1981)

Even if tuna eggs escape unscathed, the hatched larvae face a loss of food supply. Oil reduces primary production of phytoplankton and zooplankton, on which larval fish depend for food, says Shirley, which implies that few tuna larvae are likely to survive in the oiled sections of the Gulf this year.

Joe Griffitt, an aquatic toxicologist at Mississippi's Gulf Coast Research Laboratory, has collected bluefin tuna larvae that he will examine for oil exposure. He would like to collect organ samples from adult tuna to analyse exposure and effects, but for such assessments, "bluefin tuna are really hard to catch", he says. 


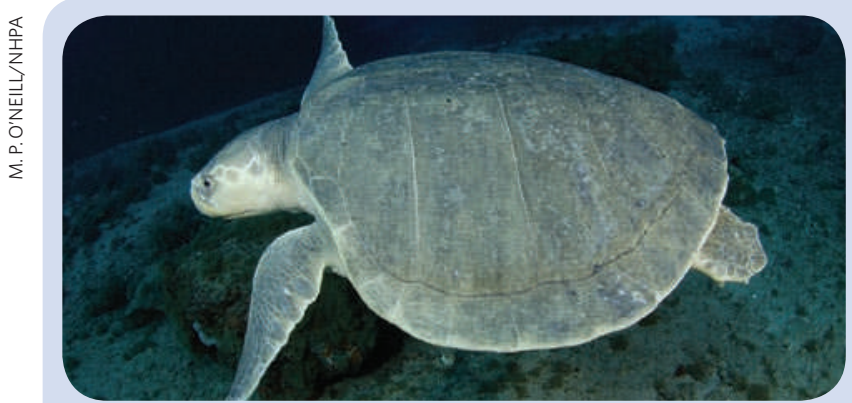

Species: Kemp's Ridley sea turtle (Lepidochelys kempii) Risk: External exposure to oil causes burns and infections. Ingestion or inhalation damages digestive and respiratory systems, liver, kidney and brain; causes immune suppression, reproductive failure and death.

Exposure: Females are known to enter the spill area post-nesting. Juveniles and adults forage there. More than $\mathbf{4 2 5}$ dead sea turtles have been reported in the spill zone and conservationists fear that more have been killed where oil was ignited to control its spread.
The Kemp's Ridley sea turtle nests in Mexico and south Texas, far from the spill. But between 1997 and 2006, Donna Shaver, chief of sea-turtle science and recovery for the US National Park Service in Corpus Christi, Texas, tagged females with transmitters and found that after nesting, they travelled northwards along the coastline to the northern and eastern Gulf, the area of the current spill. Now, says Elizabeth Wilson, marine scientist and fisheries campaign manager with the conservation group Oceana in Washington DC, "we need more satellite tagging for sea turtles to know if they're going into the oil and how they're impacted."

Established tracking programmes
OIL-SPILL HEALTH RISKS UNDER SCRUTINY

Chemical exposure concerns mount. go.nature.com/vCEZDg

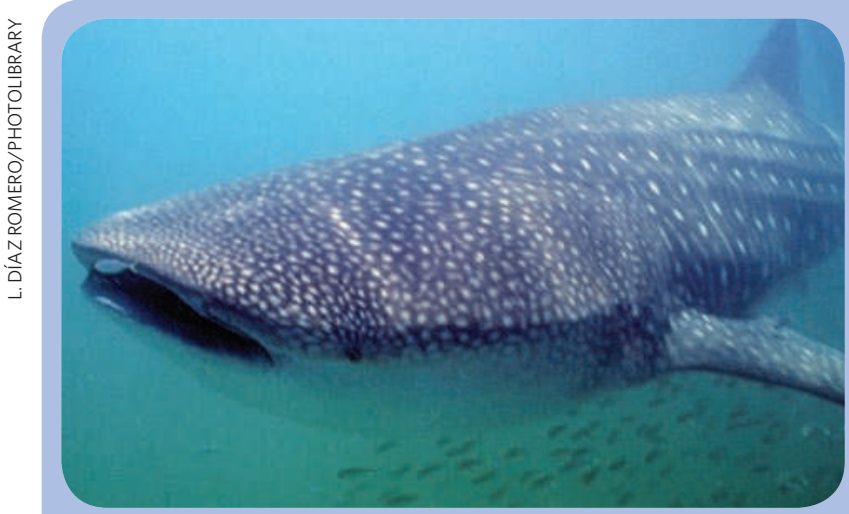

Species: Whale shark (Rhincodon typus)

Risk: Direct contact with oil could fatally coat gills. Oil could reduce or contaminate plankton, the whale shark's primary food source.

Exposure: Unknown, but exposure to oil is likely despite the short window of time that the animals spend in the Gulf.
The world's largest fish, whale sharks are filter feeders that subsist on fish spawn and plankton blooms - foods typically available off the Mississippi River delta in the summer. Of the Gulf whale-shark sightings Hoffmayer has compiled since 2002, more than one-third fall within the spill area. In a preliminary aerial survey on 24 June, he and his team spotted more than 100 whale sharks at Ewing Bank, just west of the spill. "They'll show up looking for food and find oil," says Hoffmayer.

Since the spill began, Hoffmayer has been scrambling for resources to tag and track the animals. "We need real-time data on whether whale sharks are going into the oil," he says. "There's a very short window, as they are in the Gulf from May through mid- record the number of nesting females, but the fraction of eggs that produce viable young also needs to be monitored, says Wilson. She stresses that this is long-term research, because hatchlings born this season will not reach reproductive age for years. Hatchlings moving out into open water, where they may encounter oil, need to be monitored too.

Shaver is currently attaching transmitters to female turtles nesting on the Texas coast. She is working on a proposal to take blood, tissue and carapace samples from this year's nesting females - which, given their known mating behaviour, have probably not been exposed to oil and during the next two seasons, to check for signs of oil exposure.

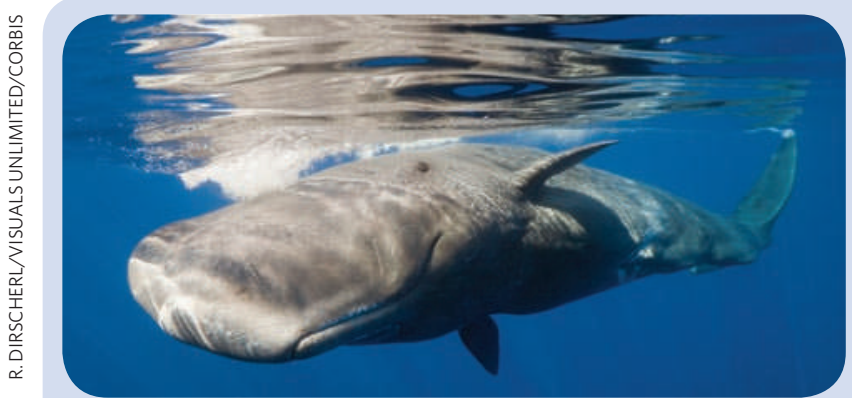

Species: Sperm whale (Physeter macrocephalus)

Risk: Inhaling volatile components can lead to unconsciousness, pneumonia, organ damage and death. Direct contact with oil and dispersants causes skin and eye infections. Oil in prey accumulates in tissue, causing disease and a decreased reproductive rate.

Exposure: Unknown, but sperm whales are known to inhabit the spill area.
About 1,700 vulnerable sperm whales live year-round in the Gulf, rarely straying from essential habitat within 100 kilometres of the Mississippi River delta - the area of the spill. The animals breathe at the surface and dive deep to feed on squid, exposing the whales to oil and dispersants at a range of depths. They typically spend nine minutes at the surface to breathe, says Heather Heenehan, a study fellow at Woods Hole Oceanographic Institution in Massachusetts. Exposure to surface slicks may be highest before a deep feeding dive, when they may remain at the surface for up to an hour, blowing more than 50 times.

Passive acoustic buoys could show the location and movements of the
September." Because sharks sink when they die, he adds, it will be impossible to know how many are affected if there is no tagging or aerial surveillance.

Collection of tissue samples is also crucial, says Lee Fuiman, director of the University of Texas Marine Science Institute in Port Aransas. "There are physiological biomarkers that will tell us whether they've been exposed to oil. Knowing that would help us understand the magnitude of impact."

Tracking surveys have previously confirmed that whale-shark populations in the northern Gulf and the Caribbean are connected, and genetic studies suggest that they make up a single global population. Thus, the effects of the spill on whale sharks are likely to reverberate worldwide. whales, Heenehan notes, and tagging would provide that information for individuals. Shirley adds that tissue samples from sperm-whale blubber, sloughed skin or faeces would help to determine the animals' oil exposure. But no sampling or tagging programmes are currently under way.

A long-term evaluation of killerwhale populations near the Exxon Valdez spill showed an increase in mortality and a decrease in birth rates (C. O. Matkin et al. Mar. Ecol. Prog. Ser. 356, 269-281; 2008). One population lost $40 \%$ of its individuals and has not recovered. A similar, long-term study of the Gulf's sperm-whale population would be valuable, Heenehan says, but it would need to begin soon. 